\title{
ZAKAZ ARBITRALNEGO WYDALANIA CUDZOZIEMCÓW W ŚWIETLE ART. 1 PROTOKOLU NR 7 DO EKPC I JEGO REALIZACJA W POLSKIM PRAWIE I PRAKTYCE - WYBRANE PROBLEMY*
}

\section{WPROWADZENIE}

Bezpieczeństwo publiczne stanowi tę wartość interesu publicznego, której ochrona uzasadnia wprowadzenie ograniczeń w korzystaniu z praw i wolności jednostki. Nie ulega wątpliwości, że bezpieczeństwo publiczne wyraża jedna z kluczowych sfer polityki państwa, obligując władze publiczne do wprowadzania wszelkich możliwych środków zapobiegawczych przy jednoczesnym poszanowaniu gwarancji demokratycznego państwa prawnego. Realizacja tych założeń ostatnio nabrała jednak innego wymiaru z uwagi na trwająca walkę z terroryzmem. Należy bowiem zauważyć, że w obecnej sytuacji cudzoziemcy stali się niejako „pierwszymi podejrzanymi”, którzy stanowią zagrożenie dla bezpieczeństwa państwa. Przekonanie to sprawia, że państwa są skłonne do ich wydalania w arbitralny sposób.

Przez arbitralne wydalenie należy rozumieć wydalenie niezgodne z obowiązującymi przepisami, polegające na nadużyciu przez państwo prawa do wydalenia ${ }^{1}$. Innymi słowy, wydalenie ma arbitralny charakter, gdy zostaje podjęte na podstawie ukrytych, niedozwolonych, nieuzasadnionych działań państwa, np. w celu przejęcia majątku cudzoziemca, lub sama procedura wydalenia jest przeprowadzana z naruszeniem podstawowych gwarancji proceduralnych i praw człowieka².

Zakaz arbitralnego wydalania cudzoziemców został expressis verbis wyrażony w art. 1 Protokołu nr 7 do Konwencji o ochronie praw człowieka i podstawowych wolności ${ }^{3}$. Zgodnie z tym przepisem:

* Artykuł powstał na podstawie grantu NCN nr 2015/17/D/HS5/00406 na realizację projektu pt. „Dostęp cudzoziemca do akt w procedurze wydaleniowej w świetle prawa polskiego i europejskiego" w ramach konkursu Sonata 9.

1 J. Wojnowska-Radzińska, The Right of an Alien to be Protected against Arbitrary Expulsion in International Law, Leiden-Boston 2015, s. 39.

2 P. Hassan, dokonując analizy terminu ,arbitralny” w Powszechnej deklaracja praw człowieka, stwierdził, iż sformułowanie to ma na celu ochronę jednostki przed dowolnymi, bezprawnymi (illegal) i niesprawiedliwymi (unjust) działaniami państwa, zmierzającymi do naruszenia przysługujących jej praw. P. Hassan, The word 'arbitrary' as used in the Universal Declaration of Human Rights: 'illegal' or 'unjust’, „Harvard International Law Journal” 10, 1969, s. 225-262.

3 Dalej jako: EKPC. 
1. Cudzoziemiec przebywający legalnie na terytorium jakiegokolwiek państwa nie może być zeń wydalony, chyba że w wyniku decyzji podjętej zgodnie z ustawa, i powinien mieć możliwość:
a) przedstawienia racji przeciwko wydaleniu;
b) wniesienia środków odwoławczych oraz
c) bycia reprezentowanym dla tych celów przed właściwym organem albo osobą lub osobami wyznaczonymi przez ten organ.
2. Cudzoziemiec może być wydalony, bez uprzedniego skorzystania ze swoich praw wymie- nionych w ustępie 1a, b i c niniejszego artykułu, jeśli jest to konieczne z uwagi na porządek publiczny lub uzasadnione względami bezpieczeństwa państwowego ${ }^{4}$.

Polska ratyfikowała EKPC 19 stycznia 1993 r., a 4 listopada 2002 r. - Protokół nr 7. Miejsce Konwencji i Protokołów dodatkowych w polskim systemie źródeł prawa określa Konstytucja RP w art. 87, uznając, iż ratyfikowane umowy międzynarodowe są źródłem powszechnie obowiązującego prawa. Oznacza to, że EKPC jest źródłem prawa, które może być stosowane bezpośrednio. Dodatkowa gwarancję realizacji podstawowych praw i wolności jednostki wynikających z tych aktów stanowi art. 9 Konstytucji RP, zgodnie z którym Rzeczpospolita Polska przestrzega wiążącego ją prawa międzynarodowego. Konstytucyjna zasada poszanowania prawa międzynarodowego stanowi niewątpliwie zasadniczy punkt odniesienia przy ocenie wpływu porządku prawnomiędzynarodowego na polski porządek prawny.

\section{WYMOGI PRAWNE DECYZJI O WYDALENIU}

Podstawowym celem art. 1 Protokołu nr 7 jest zapewnienie cudzoziemcowi gwarancji proceduralnych przed arbitralnym wydaleniem ${ }^{5}$. Należy zauważyć, że omawiany przepis zawiera nie tylko szereg uprawnień o charakterze formalnym, ale przewiduje także, że cudzoziemiec legalnie przebywajacy na terytorium państwa może być z niego wydalony jedynie w wyniku decyzji podjętej zgodnie $\mathrm{z}$ prawem (in accordance with law), co oznacza, że prawo krajowe powinno określać organ właściwy w sprawach wydalania cudzoziemców oraz zasady i tryb postępowania w tych sprawach ${ }^{6}$. Na tej właśnie podstawie uznaje się, że przedmiotowy przepis odwołuje się do zasady legalności (principle of legality) ${ }^{7}$.

Europejski Trybunał Praw Człowieka (ETPC) bada na podstawie art. 1 Protokołu nr 7, czy decyzja o wydaleniu została podjęta przez właściwy organ

${ }^{4}$ Dz. U. 2003, Nr 42, poz. 364; w Polsce Protokół nr 7 wszedł w życie 1 marca 2003 r.

${ }^{5}$ S. Jagerskiold, The freedom of movement, w: L. Henkin, The International Bill of Rights. The Covenant on Civil and Political Rights, New York 1981, s. 184.

${ }^{6}$ G. S. Goodwin-Gill, International Law and Movement of Persons between States, Oxford 1978, s. 263. Państwo powinno bowiem przestrzegać swojego prawa w myśl rzymskiej paremii: Patere legem quam ipse fecisti (poddaj się prawu, któreś sam ustanowił). Zob. także: Explanatory Report on Protocol No. 7 to the Convention for the Protection of Human Rights and Fundamental Freedoms, ETS No. 117, par. 11.

${ }^{7}$ Zasada legalności wymaga, aby każdy akt władczej ingerencji organu administracji państwowej w sferę prawną obywatela oparty był na konkretnie wskazanym przepisie prawa. 
zgodnie z przepisami prawa materialnego i odpowiednimi zasadami o charakterze proceduralnym ${ }^{8}$. W sprawie Bolat $p$. Rosji Trybunał stwierdził naruszenie art. 1 Protokołu nr 7, gdyż cudzoziemiec został wydalony z Rosji bez orzeczenia sądowego, które było wymagane w takim przypadku przez prawo krajowe. Trybunał wskazał bowiem, iż nie można przyjąć, że cudzoziemiec ten został wydalony w wyniku decyzji podjętej zgodnie z ustawą 9 .

W literaturze i orzecznictwie podkreśla się, że w celu wyeliminowania arbitralności prawo regulujące wydalanie cudzoziemców powinno zawierać dwa elementy: dostępność (accessibility) i przewidywalność (forseeability) ${ }^{10}$. Dostępność prawa oznacza możliwość zapoznania się z jego treścia. Spełnienie tego wymogu następuje przez opublikowanie ustawy w taki sposób, by adresaci norm mogli zapoznać się z jej treścią. Przewidywalność jest natomiast związana z jasnością i przejrzystością tekstu ustawy oraz możliwością określenia przez cudzoziemców skutków prawnych ich zachowania. Powszechnie przyjmuje się, że w powołanych przesłankach mieści się wymóg odpowiedniej jakości prawa (quality of law), które reguluje sytuację prawną cudzoziemca ${ }^{11}$.

ETPC podkreślił, że wymóg przewidywalności prawa nie sięga jednak tak daleko, aby zmuszać państwo do wprowadzania regulacji prawnych wymieniajacych szczegółowo każde zachowanie, które może uzasadniać wydanie decyzji o wydaleniu ze względu na bezpieczeństwo państwa ${ }^{12}$. Mimo że zagrożenie ze strony cudzoziemca dla bezpieczeństwa państwa może mieć różny charakter, to w każdym jednak przypadku organy niezależne od tych, które podjęły decyzję o wydaleniu, muszą być zdolne, jak zwrócił uwagę Trybunał, „do zareagowania w sprawach, gdy decyzja taka nie znajduje oparcia w okolicznościach faktycznych lub ujawnia interpretację pojęcia bezpieczeństwa państwa jako sprzeczną z prawem lub arbitralną"13.

\section{GWARANCJE PROCEDURALNE PRZYSŁUGUJĄCE CUDZOZIEMCOWI NA PODSTAWIE ART. 1 PROTOKOŁU NR 7 DO EKPC}

Decyzja o wydaleniu wraz z zarzutami i uzasadnieniem powinna być przedłożona cudzoziemcowi w języku dla niego zrozumiałym. Cudzoziemiec ma prawo znać powody swego wydalenia, a państwo ma obowiązek mu je

\footnotetext{
${ }^{8}$ Council of Europe, Explanatory report on Protocol No. 7 to the Convention for the Protection of Human Rights and Fundamental Freedoms, par. 11. Zob. także: orzeczenie ETPC z 2 grudnia 1987 r., Bozano p. Francji, skarga nr 9990/82.

${ }^{9}$ Orzeczenie ETPC z 5 października 2006 r., Bolat p. Rosji, skarga nr 14139/03, par. 81-82.

${ }_{10}$ M. Pellonpaa, International Law and Expulsion of Aliens, Helsinki 1984, s. 103-110; P. Boeles et al., European Migration Law, Antwerp-Oxford-Portland 2009, s. 150.

${ }_{11}$ Orzeczenie ETPC z 20 czerwca 2002 r., Al-Nashif p. Butgarii, skarga nr 50963/99, par. 119. Zob. także orzeczenia ETPC: z 8 czerwca 2006 r., Lupsa p. Rumunii, skarga nr 10337/04; z 6 grudnia 2007 r., Liu i Liu p. Rosji, skarga nr 42086/05 i z 24 kwietnia 2008 r., C.G. $i$ inni p. Butgarii, skarga nr 1365/07, par. 39, 40.

${ }^{12}$ Orzeczenie ETPC z 20 czerwca 2002 r., Al-Nashif p. Bułgarii, skarga nr 50963/99, par. 121.

${ }^{13}$ Ibidem, par. 124.
} 
przedstawić. Przy wydalaniu cudzoziemców zasadniczym problemem jest jednak zakres i stopień konkretyzacji przesłanek będących podstawą wydalenia. W sprawie Lupsa p. Rumunii skarżący podniósł, że nigdy nie został powiadomiony o przyczynach wydalenia ${ }^{14}$. Organy krajowe ograniczyły się tylko do stwierdzenia, że jego pobyt w Rumunii zagraża bezpieczeństwu państwa i na tej podstawie uznano jego obecność za niepożądaną. Trybunał stwierdził, że niezależnie od ochrony z art. 3 i 8 łącznie z art. 13 EKPC, cudzoziemcowi przysługuje ochrona przewidziana $\mathrm{w}$ art. 1 Protokołu $\mathrm{nr}$ 7. Trybunał zauważył, że w rozpoznawanej sprawie nie prowadzono przeciwko skarżącemu żadnego postępowania $\mathrm{w}$ sprawie popełnienia jakiegokolwiek wykroczenia w Rumunii czy w innym państwie. Władze Rumunii nie udzieliły skarżącemu żadnych wyjaśnień w sprawie przestępstw, o których popełnienie był podejrzany. Naruszono również prawo krajowe, dopiero bowiem po wydaleniu doręczono mu zarządzenie, na mocy którego uznano jego obecność za niepożądaną. Ponadto organy administracji publicznej nie przedstawiły sądowi apelacyjnemu żadnych dowodów wskazujących na istnienie zagrożenia bezpieczeństwa państwa ze strony cudzoziemca. Z kolei sąd nie tylko nie zweryfikował twierdzeń, czy cudzoziemiec $\mathrm{w}$ rzeczywistości stwarzał zagrożenie dla bezpieczeństwa państwa i porządku publicznego, ale także oddalił wszystkie wnioski dotyczące odroczenia rozprawy, uniemożliwiając obrońcy skarżącego zapoznanie się z zarządzeniem prokuratora. Trybunał podkreślił, że żadna osoba, w stosunku do której zastosowano środek oparty na przesłance bezpieczeństwa państwa, nie może być pozbawiona koniecznych gwarancji przeciwko arbitralności. Tym samym Trybunał stwierdził, iż doszło do naruszenia art. 1 Protokołu nr 7, ponieważ w postępowaniu przed władzami krajowym skarżącemu nie zapewniono nawet $\mathrm{w}$ minimalnym stopniu ochrony przed arbitralnościa.

Warto odwołać się do sprawy C.G. $i$ inni p. Bułgarii, w której wydalenie nastapiło jeszcze w dniu wydania decyzji, w wyniku czego skarżący nie mógł skorzystać z gwarancji proceduralnych z art. 1 Protokołu nr 7. Trybunał orzekł, że względy bezpieczeństwa państwowego, na które powoływały się władze Bułgarii na podstawie ust. 2 tego przepisu, nie mogły mieć tutaj zastosowania, w związku z czym został naruszony powyższy przepis ${ }^{15}$. Natomiast w sprawie Nolan i K. p. Rosji Trybunał wyraził pogląd, że państwo narusza art. 1 ust. 1 Protokołu nr 7, gdy decyzja o wydaleniu nie jest podana do wiadomości cudzoziemcowi przez okres trzech miesięcy, nie zezwala mu się na przedstawienie argumentów przeciwko wydaleniu, a pełnomocnik cudzoziemca nie może uczestniczyć w procedurze kontroli decyzji o wydaleniu ${ }^{16}$.

Prawo do przedstawienia argumentów przeciwko wydaleniu stanowi kolejna gwarancję proceduralną zagwarantowaną przez art. 1 Protokołu nr 7 do EKPC. Jest ono odzwierciedleniem elementarnej zasady demokratyczne-

\footnotetext{
${ }_{14}$ Orzeczenie ETPC z 8 czerwca 2006 r., Lupsa p. Rumunii, skarga nr 10337/04. Zob także orzeczenia ZETPC: z 15 lutego 2011 r., Geleri p. Rumunii, skarga nr 33118/05; z 14 czerwca 2007 r., Bashir and Others p. Butgarii, skarga nr 65028/01, par. 41-42; z 2 września 2010 r., Kaushal i inni p. Butgarii, skarga nr 1537/08.

15 Orzeczenie ETPC z 24 kwietnia 2008 r., C.G. $i$ inni p. Butgarii, skarga nr 1365/07.

${ }^{16}$ Orzeczenie ETPC z 12 lutego 2009 r., Nolan $i$ K. p. Rosji, skarga nr 2512/04.
} 
go państwa prawnego, znanej jako audi alteram partem (należy wysłuchać drugiej strony). Prawo to daje cudzoziemcowi możliwość ustosunkowania się do stawianych mu zarzutów ${ }^{17}$. W Komentarzu wyjaśniającym do art. 1 Protokołu nr 7 do EKPC wskazuje się, że cudzoziemiec może korzystać z prawa do przedstawienia swoich argumentów przeciwko wydaleniu, nawet przed rozpatrzeniem jego sprawy przez właściwy organ ${ }^{18}$. Trybunał kilkakrotnie zwracał uwagę, że osoba, w stosunku do której zastosowano wydalenie ze względu na ochronę bezpieczeństwa państwa, musi mieć możliwość przeprowadzenia postępowania przed niezależnym i bezstronnym organem, kompetentnym do ustalenia wszystkich istotnych okoliczności faktycznych oraz przepisów prawa w celu stwierdzenia legalności zastosowanego środka w postaci wydalenia. Przed takim organem cudzoziemiec musi mieć zapewniony udział w postępowaniu kontradyktoryjnym, w którym może przedstawić swój punkt widzenia i zakwestionować argumenty władz ${ }^{19}$. Tym samym Trybunał odwołuje się do zasad rzetelnego procesu w sprawach dotyczących wydalania cudzoziemców z kraju legalnego pobytu.

W przypadku podjęcia przez państwo decyzji o wydaleniu cudzoziemcowi powinna przysługiwać również możliwość odwołania się od takiej decyzji do właściwej władzy w celu stwierdzenia legalności zastosowanego środka ${ }^{20}$. Ponadto wymaga podkreślenia, że Zgromadzenie Parlamentarne Rady Europy zaleciło w swoich rekomendacjach, iż cudzoziemcy wydalani z krajów Rady Europy powinni mieć prawo do wniesienia odwołania o charakterze suspensywnym ${ }^{21}$.

Jeśli chodzi o samo rozpatrzenie sprawy o wydalenie, to nie musi ono przybierać formy dwuinstancyjnej procedury prowadzonej przed różnymi organami. Istota tej gwarancji, jak wynika z Komentarza wyjaśniającego, zakłada jedynie to, iż kompetentny organ rozpatrzy sprawę ponownie w świetle okoliczności powoływanych przez cudzoziemca i przemawiajacych przeciwko wydaleniu ${ }^{22}$. Ponadto cudzoziemiec i jego przedstawiciel nie muszą być fizycznie obecni przed organem rozpatrujacym odwołanie od decyzji o wydaleniu. Artykuł 1 Protokołu nr 7 do EKPC nie wymaga bowiem prowadzenia ustnego postępowania, co oznacza, że może odbyć się w formie pisemnej ${ }^{23}$.

Należy zauważyć, że cechą charakterystyczną omawianych gwarancji proceduralnych przewidzianych w art. 1 Protokołu nr 7 jest ich relatywny charak-

${ }^{17}$ J. Chlebny, Ochrona interesu publicznego a prawo cudzoziemca do pobytu w Polsce, „Europejski Przegląd Sądowy" 2007, nr 10, s. 21.

18 Explanatory Report on Protocol No. 7 to the Convention for the Protection of Human Rights and Fundamental Freedoms, ETS No. 117, par. 13.1.

${ }_{19}$ Orzeczenie ETPC z 8 czerwca 2006 r., Lupsa p. Rumunii, skarga nr 10337/04, par 38; zob. także: orzeczenie ETPC z 20 czerwca 2002 r. Al-Nashif p. Bułgarii, par. 123.

${ }^{20}$ Zob. J. Wojnowska-Radzińska, Prawo cudzoziemca do odwołania $w$ procedurze wydaleniowej w świetle Konwencji o ochronie praw człowieka i podstawowych wolności, „Ruch Prawniczy, Ekonomiczny i Socjologiczny" 75, 2013, z. 3, s. 21-33.

21 Parliamentary Assembly of the Council of Europe, Recommendation 1624(2003): Common policy on migration and asylum, przyjęte 30 września 2003 r., par. 9.

${ }^{22}$ Explanatory Report on Protocol No. 7 to the Convention for the Protection of Human Rights and Fundamental Freedoms, ETS No. 117, par. 13.2.

${ }^{23}$ P. Boeles, Fair Immigration Proceedings in Europe, The Hague 1997, s. 287. 
ter, tzn. możliwość uchylenia w sytuacji nadzwyczajnej dyktowanej interesem porządku publicznego lub względami bezpieczeństwa państwa (art. 1 ust. 2). Przesłanki te pozostawiają państwu szeroki margines uznania ze względu na ogólność tych pojęć. Z tego względu wydalanie cudzoziemców nie może być całkowicie zobiektywizowane, gdyż zasadnicze przesłanki, leżące u jego podstaw: ochrona bezpieczeństwa państwa i porządku publicznego nie zostały normatywnie zdefiniowane. Stwarza to poważne kłopoty w trakcie wykładni norm prawnych i dopuszcza nader zróżnicowane interpretacje tych pojęć - w szczególności bezpieczeństwa państwa - a tym samym istnieje ryzyko dowolności w ich stosowaniu.

Zdaniem Trybunału możliwość odstapienia od gwarancji wymienionych w art. 1 ust. 1 Protokołu nr 7 jest możliwa tylko przed wydaleniem i nie dotyczy etapu postępowania trwającego już po wykonaniu decyzji. Należy zatem podkreślić, że cudzoziemiec, który jest wydalany na podstawie art. 1 ust. 2, może powoływać się na gwarancje proceduralne przewidziane w art. 1 ust. 1 dopiero po jego faktycznym wydaleniu z terytorium danego państwa ${ }^{24}$. Natomiast cudzoziemiec, który jest wydalany na podstawie innych przyczyn niż wymienione w art. 1 ust. 2, ma zapewniona możliwość powoływania się na te gwarancje przed ewentualną deportacją.

Z Komentarza wyjaśniającego do Protokołu nr 7 jednoznacznie wynika, że uznanie wydalenia cudzoziemca za konieczne ze względu na porządek publiczny lub uzasadnione względami bezpieczeństwa państwowego musi odpowiadać zasadzie proporcjonalności, tak jak została ona zdefiniowana w orzecznictwie $\mathrm{ETPC}^{25}$. Andrzej Wróbel wskazuje, że sformułowania: „konieczne z uwagi na” oraz „uzasadnione względami” oznaczaja, że chodzi tu wyłącznie o konieczność i zasadność ze względu na te dwa legitymowane cele ${ }^{26}$. Katalog tych przesłanek ma charakter enumeratywny, a co za tym idzie, żadne inne okoliczności poza wymienionymi nie mogą być podstawą uchylenia przysługujących cudzoziemcowi gwarancji proceduralnych. Zatem badanie przesłanki z art. 1 ust. 2 Protokołu nr 7 „konieczne z uwagi” lub „uzasadnione względami”, jak wyjaśnia A. Wróbel, ogranicza się jedynie do testu proporcjonalności, czyli relacji między wydaleniem jako środkiem a porządkiem publicznym lub bezpieczeństwem państwa jako celami ${ }^{27}$. Istotne jest przy tym zachowanie właściwej równowagi pomiędzy uprawnionym celem ingerencji a interesem indywidualnym. Aby utrzymać tę równowagę między konkurującymi ze sobą interesami jednostki i społeczeństwa, zastosowany środek, jakim jest wydalenie, musi być proporcjonalny do celu, któremu ma służyć.

${ }^{24}$ Explanatory Report on Protocol No. 7 to the Convention for the Protection of Human Rights and Fundamental Freedoms, ETS No. 117, par. 15. Zob. także: orzeczenie ETPC z 8 czerwca 2006 r., Lupsa p. Rumunii, skarga nr 10337/04, par. 53; I. Cameron, National Security and the European Convention on Human Rights, Uppsala 2000, s. 431.

${ }^{25}$ Explanatory Report on Protocol No. 7 to the Convention for the Protection of Human Rights and Fundamental Freedoms, ETS No. 117, par. 15.

${ }^{26}$ A. Wróbel, Protokót nr 7 do Konwencji o ochronie praw człowieka i podstawowych wolności, w: L. Garlicki, P. Hofmański, A. Wróbel, Konwencja o Ochronie Praw Człowieka i Podstawowych Wolności. Komentarz do art. 19-59, t. 2, Warszawa 2010, s. 628,

27 Ibidem. 
Europejski Trybunał Praw Człowieka wielokrotnie zwracał uwagę, że przed nadużywaniem pojęcia „bezpieczeństwo państwa” chroni cudzoziemca przede wszystkim istnienie postępowania kontradyktoryjnego przed bezstronnym organem uprawnionym do dokonania niezależnej kontroli przesłanek decyzji o wydaleniu oraz zgromadzonego materiału dowodowego. Chociaż Trybunał akceptował, że w ramach wymaganej procedury kontradyktoryjnej moga zostać wprowadzone „odpowiednie ograniczenia” dotyczace informacji objętych klauzulą tajności, to jednocześnie podkreślał, iż konwencyjnego standardu nie spełnia procedura krajowa, na podstawie której nie zapoznano cudzoziemca podlegającego wydaleniu ani jego pełnomocnika ze stawianymi mu zarzutami, poza ogólnym wskazaniem na zagrożenie dla bezpieczeństwa państwa ${ }^{28}$.

\section{OCHRONA CUDZOZIEMCÓW PRZED ARBITRALNYM WYDALENIEM W USTAWIE O CUDZOZIEMCACH}

Decyzja o wydaleniu cudzoziemca z terytorium Rzeczypospolitej Polskiej wydawana jest $\mathrm{w}$ postępowaniu administracyjnym $\mathrm{z}$ zachowaniem szeregu gwarancji procesowych i środków jej kontroli na drodze administracyjnej oraz sądowej $^{29}$. Na podstawie art. 302 ust. 1 pkt 9 ustawy z 12 grudnia 2013 r. ${ }^{30}$ o cudzoziemcach decyzję o zobowiązaniu cudzoziemca do powrotu wydaje się cudzoziemcowi, gdy wymagają tego względy obronności lub bezpieczeństwa państwa lub ochrony bezpieczeństwa i porządku publicznego lub interes Rzeczypospolitej Polskiej. Decyzję taka podejmuje organ administracyjny ${ }^{31}$. W tym zakresie organ został jednak zobowiązany przez polskie sady administracyjne do przeprowadzenia stosownego rozumowania i wskazania na fakty, które przesądzają o istniejącym zagrożeniu ze strony cudzoziemca ${ }^{32}$.

28 Zob. orzeczenia ETPC: z 8 czerwca 2006 r., Lupsa p. Rumunii, skarga nr 10337/04, par. 38; z 20 czerwca 2002 r., Al-Nashif p. Butgarii, skarga nr 50963/99, par. 123. Zob. także: R. White, C. Ovey, The European Convention on Human Rights, Oxford 2010, s. 545.

${ }^{29}$ J. Borkowski, Prawo o cudzoziemcach. Komentarz, pod redakcją J. Chlebnego, Warszawa, 2006 , s. 205.

${ }^{30}$ Dz. U. 2013, poz. 1650 ze zm. (dalej jako: u.o.c.). Wymaga podkreślenia, że decyzja o wydaleniu cudzoziemca z terytorium Rzeczypospolitej Polskiej została zastapiona w nowej ustawie o cudzoziemcach decyzją o zobowiązaniu cudzoziemca do powrotu.

${ }^{31}$ Zgodnie z art. 310 u.o.c. decyzję o zobowiązaniu cudzoziemca do powrotu podejmuje: 1) z urzędu - komendant oddziału Straży Granicznej lub komendant placówki Straży Granicznej, który stwierdził istnienie przesłanki uzasadniającej wydanie decyzji o zobowiązaniu cudzoziemca do powrotu; 2) na wniosek wojewody, Ministra Obrony Narodowej, Szefa Agencji Bezpieczeństwa Wewnętrznego, Szefa Agencji Wywiadu, Szefa Służby Kontrwywiadu Wojskowego, Szefa Służby Wywiadu Wojskowego, organu Służby Celnej, komendanta wojewódzkiego lub komendanta powiatowego (miejskiego) Policji - komendant oddziału Straży Granicznej lub komendant placówki Straży Granicznej właściwy ze względu na siedzibę organu występującego z wnioskiem albo miejsce pobytu cudzoziemca.

${ }^{32}$ Wyrok NSA z 31 lipca 2001 r., V SA 501/01. 
Pojęcie „względy bezpieczeństwa państwowego” lub „ochrony bezpieczeństwa i porządku publicznego" są pojęciami nieostrymi, które stwarzają pewien luz decyzyjny dla podmiotu stosującego prawo, w związku z tym intuicyjnie przypisywana mu treść musi być uszczegółowiona w konkretnych sprawach. Pojęcie bezpieczeństwa państwa powinno być traktowane w praktyce niezwykle precyzyjnie, co oznacza, że państwo odwołujące się do niego powinno wskazać na istnienie niebudzącego wątpliwości, poważnego zagrożenia o charakterze politycznym bądź militarnym dla całego narodu (np. szpiegostwo, akty terroryzmu).

W świetle wyrażanych w orzecznictwie poglądów: „ocena przesłanek uzasadniających wydalenie musi być dokonana w kontekście istniejących zagrożeń ze strony cudzoziemca dla porządku publicznego, a nie zagrożeń hipotetycznych i opierających się na dowolnym uznaniu organów" ${ }^{33}$. Z kolei w wyroku z 21 marca 2001 r. Naczelny Sąd Administracyjny stwierdził, iż argument konieczności ochrony porządku publicznego musi być proporcjonalny do naruszenia ze strony cudzoziemca. Niedopuszczalne jest kwalifikowanie błahych uchybień lub nieświadomych naruszeń jako podstawy wydalenia cudzoziemca ze względu na zagrożenie bezpieczeństwa i porządku publicznego, bez uwzględnienia innych okoliczności w sprawie ${ }^{34}$. Przyjęto, iż w każdym przypadku organ orzekajacy ma obowiązek wskazać, jaki interes Rzeczypospolitej Polskiej może zostać naruszony, i udowodnić, że jest on na tyle ważny, że wymaga ograniczenia uprawnień indywidualnych ${ }^{35}$. Jeśli w decyzji o wydaleniu cudzoziemca brak takiego wyjaśnienia, to należy uznać, że decyzja została wydana bez przeprowadzenia odpowiedniego postępowania wyjaśniającego.

$\mathrm{Z}$ uwagi na fakt, że decyzja o zobowiązaniu cudzoziemca do powrotu ma charakter decyzji administracyjnej, powinna zawierać na podstawie art. 107 ust. 1 Kodeksu postępowania administracyjnego (k.p.a.) następujące elementy: oznaczenie organu administracji publicznej, datę wydania, oznaczenie strony lub stron, powołanie podstawy prawnej, rozstrzygnięcie, uzasadnienie faktyczne i prawne, pouczenie, czy i w jakim trybie służy od niej odwołanie, podpis z podaniem imienia i nazwiska oraz stanowiska służbowego osoby upoważnionej do wydania decyzji ${ }^{36}$. W orzecznictwie przyjmuje się, że uzasadnienie decyzji powinno zawierać wskazanie faktów, które organ administracji uznał za udowodnione, gdyż przy braku takiego wskazania pojawia się zasadnicza wątpliwość, czy ustalenie podstawy faktycznej jest prawidłowe ${ }^{37}$. Jednakże u.o.c. wprowadza ograniczenie co do uzasadnienia decyzji o zobowiązaniu cudzoziemca do powrotu. Zgodnie z art. 6 ust. 1 ustawy, organ wydający decyzję lub postanowienie w postępowaniu prowadzonym na podstawie przepisów ustawy może odstapić od uzasadnienia, w całości lub w części, jeżeli wymagają tego względy obronności lub bezpieczeństwa państwa albo ochrony bezpieczeństwa i porządku publicznego. Należy jednocześnie podkreślić, że możliwość odstapienia od uzasadnienia decyzji nie zwalnia organu prowa-

\footnotetext{
${ }^{33}$ Wyrok NSA z 30 listopada 2006 r., II OSK 1475/05.

${ }^{34}$ Wyrok NSA z 21 marca 2001 r., V SA 2662/00.

35 Wyrok NSA z 21 czerwca 2001 r., 3718/00.

36 Dz. U. 2000, Nr 98, poz. 1071.

37 Wyrok NSA z 30 grudnia 1987 r., S.A./Gd 1045/87, OSNA 1987, nr 2, poz. 94.
} 
dzącego postępowanie od obowiązku zgromadzenia pełnego materiału dowodowego i przedstawienia go sądowi administracyjnemu. Zatem odstapienie od uzasadnienia ze wskazanych względów nie ogranicza możliwości obrony swoich racji przez zainteresowanego cudzoziemca zarówno w postępowaniu przed organami administracji publicznej, jak i przed niezawisłym sądem.

Cudzoziemiec będący stroną postępowania wydaleniowego ma prawo dostępu do swoich akt, sporządzania notatek, kopii lub odpisów, jak również prawo żądania uwierzytelnienia odpisów z akt sprawy, co musi uzasadnić ważnym interesem (art. 73 ust. 1 i 3 k.p.a.). Odmowa umożliwienia cudzoziemcowi przeglądania akt sprawy, sporządzania z nich notatek i odpisów musi być sformułowana $\mathrm{w}$ formie postanowienia, na które służy zażalenie. Ustawodawca zastrzegł jednak, że prawa wynikającego z art. 73 k.p.a. nie stosuje się do akt sprawy zawierających informacje niejawne o klauzuli tajności „tajne” lub ,ściśle tajne", a także do innych akt, które organ administracji publicznej wyłączy ze względu na ważny interes państwowy (art. 74 ust. 1 k.p.a.). Oznacza to, że $\mathrm{w}$ takim postępowaniu ani pełnomocnikowi, ani tym bardziej stronie, nie sa udostępniane dokumenty, których dotyczy postępowanie. Pojawia się zatem pytanie, co w sytuacji gdy cudzoziemiec ma zostać wydalony ze względu na to, że jego dalszy pobyt stanowiłby zagrożenie dla obronności lub bezpieczeństwa państwa lub ochrony bezpieczeństwa i porządku publicznego albo naruszałby interes Rzeczypospolitej Polskiej, a organ administracyjny, który wydał taka decyzję, nie może przedstawić żadnych dowodów na poparcie tej tezy, ponieważ sa tajne. Nie ulega wątpliwości, że cudzoziemiec powinien mieć w możliwym zakresie dostęp do obciążających go dokumentów, inaczej bowiem nie będzie miał szansy na skuteczna realizację prawa do obrony. W świetle standardów europejskich przyjętych w Rekomendacji (2004)20 w sprawie sądowej kontroli aktów administracyjnych - organ administracji obowiązany jest do przedstawienia sądowi dokumentów i informacji, które mają znaczenie dla sprawy, poza wyjątkowymi sytuacjami przewidzianymi przez prawo krajowej ${ }^{38}$. Autorzy tego dokumentu, powołując się na orzecznictwo ETPC, przypominaja również o obowiązku umożliwienia stronie zapoznania się z aktami, gdyż jest to warunek rzetelnego postępowania ${ }^{39}$. Jednak w stosunku do dokumentów zawierajacych dane podlegajace ochronie (np. z powodu bezpieczeństwa państwa) zezwala się na stosowanie specjalnych środków ochrony, aczkolwiek nie sprecyzowano, na czym takie środki maja polegać ${ }^{40}$. Należy w tej kwestii odwołać się do orzecznictwa ETPC, w którym m.in. rozpatrywano zasady korzystania $\mathrm{z}$ materiałów poufnych ${ }^{41}$. Trybunał nie wykluczył wprawdzie odmowy

${ }^{38}$ Art. 4 c Recommendation Rec(2004)20 of the Committee of Ministers to member states on judicial review of administrative acts, 15 grudnia 2004 r., https://wcd.coe.int/ViewDoc. jsp?id=802925\&Site=CM [dostęp: 3.11.2016].

39 Art. 63 memorandum wyjaśniającego, które stanowi integralną część Rekomendacji.

40 Art. 64 memorandum wyjaśniającego.

41 J. Chlebny, Sqdowa kontrola administracji w świetle rekomendacji Rady Europy, „Państwo i Prawo" 2005, z. 2, s. 28; zob. także: idem, Europejskie standardy procedury administracyjnej i sadowoadministracyjnej, w: Z. Kmieciak (red.), Postepowanie administracyjne w Europie, Kraków 2005, s. 15-38; idem, Odmowa dostępu do akt w sprawie administracyjnej, „Państwo i Prawo” 2014, z. 10 , s. 98-110. 
udostępnienia stronie akt sprawy ze względu na bezpieczeństwo państwa, ale zalecił stosowanie procedur, które nie zagrażając ujawnieniu natury i źródeł tajnych informacji, przyznaja jednocześnie stronie w pewnym zakresie dostęp do informacji zawartych w aktach administracyjnych i tym samym zapewniają istotne gwarancje proceduralne ${ }^{42}$. Przykładem wskazanym przez ETPC była praktyka stosowana w Kanadzie, polegająca na zapoznawaniu strony ze streszczeniem przebiegu postępowania prowadzonego z wyłączeniem jawności oraz zezwoleniu na udział w postępowaniu prawnika posiadającego certyfikat dostępu do informacji poufnych (a security-cleared counsel) ${ }^{43}$.

$\mathrm{Z}$ uwagi na niejawny charakter informacji stanowiacych podstawę decyzji o wydaleniu, uzasadnienie sprowadza się w praktyce do wskazania, że kierunek rozstrzygnięcia podyktowany był względami bezpieczeństwa państwa. Cudzoziemiec ma możliwość odwołania się do Szefa Urzędu do spraw Cudzoziemców, a następnie złożenia skargi na jego decyzję do sądu administracyjnego. Jednakże ze względu na niejawny charakter materiałów, do których dostępu nie ma także reprezentujacy go profesjonalny pełnomocnik, zainteresowany nie ma skutecznej możliwości zakwestionowania treści decyzji. Trudno bowiem zgodzić się z poglądem, aby uznać za wystarczające ogólne odwołanie się do kategorii bezpieczeństwa państwa bez skonkretyzowania okoliczności faktycznych dotyczacych wydalenia cudzoziemca na tyle, by mógł on skorzystać z prawa do przedstawienia argumentów przeciwko wydaleniu. Nie kwestionuję prawa uprawnionych organów do wyłączenia - ze względu na ochronę bezpieczeństwa państwa - dostępu cudzoziemca do poznania pełnej treści określonych dokumentów w procedurze wydaleniowej. Niemniej uważam, że całkowity brak możliwości dostępu do materiałów i akt zgromadzonych w trakcie procedury wydaleniowej jest nadmiernym ograniczeniem prawa cudzoziemca do dostępu do dotyczących go dokumentów. Praktyka taka wypacza bowiem zasadę kontradyktoryjności, która winna, w ocenie Trybunału Konstytucyjnego, cechować każde postępowanie sądowe, i tym samym prowadzi do odebrania takiemu postępowaniu waloru bezstronności. Należy podkreślić, iż każdemu etapowi postępowania wydaleniowego muszą towarzyszyć gwarancje prawa do obrony, adekwatne do danego etapu. Omawiana ustawa na chwilę obecną nie zawiera żadnych przepisów odnoszących się do możliwości zapoznania się przez cudzoziemca z dowodami i materiałami objętymi klauzulą tajności, potwierdzającymi, że jego dalszy pobyt stanowi zagrożenie dla bezpieczeństwa RP.

Złożoność omawianej problematyki odzwierciedla m.in. sprawa Chakiba Marakchiego, obywatela Maroka, który został wydalony z Polski pod zarzutem zagrożenia dla bezpieczeństwa Rzeczypospolitej Polskiej ${ }^{44}$. Marokańczyk przez osiem lat mieszkał legalnie w Polsce, gdzie kontynuował swoja eduka-

${ }^{42}$ Zob. orzeczenie ETPC z 15 listopada 1996 r., Chahalp. Wielkiej Brytanii, skarga nr 22414/93, par. 131 i 144.

43 J. Chlebny, Sadowa kontrola..., s. 28.

${ }^{44}$ Sprawa ta była rozpatrywana na poprzedniej ustawie z 13 czerwca 2003 r. o cudzoziemcach. Zob. także: P. Figurski, J. Sidorowicz, Nie tylko Ameer twierdzi, że ABW chce go wydalić za to, że odmówił wspótpracy, „Gazeta Wyborcza” z 26 października 2016 r., http://wyborcza. pl/7,75398,20890478,zabieraj-sie-stad-ameer.html [dostęp: 5.11.2016]. 
cję - skończył studia magisterskie i następnie rozpoczął studia doktoranckie. W marcu 2009 r. Marakchi złożył do Wojewody Małopolskiego - jak co roku - wniosek o zezwolenie na zamieszkanie na czas oznaczony. Wojewoda Małopolski odmówił udzielenia zezwolenia na zamieszkanie, powołując się na konieczność ochrony bezpieczeństwa państwa, i zobowiązał go do opuszczenia terytorium Polski. Decyzji tej został nadany rygor natychmiastowej wykonalności. Co istotne, Wojewoda wyłączył z jawnej dokumentacji materiały zawierające m.in. opinię ABW. Jednocześnie odmówił cudzoziemcowi ich przeglądania, w związku z czym odebrano mu możliwość skutecznej obrony. Marakchi wniósł odwołanie do Szefa Urzędu do spraw Cudzoziemców. W styczniu 2010 r. Szef Urzędu do spraw Cudzoziemców utrzymał jednak w mocy zaskarżona decyzję i zobowiązał cudzoziemca do opuszczenia Polski w ciagu siedmiu dni, nadając swojej decyzji rygor natychmiastowej wykonalności. Jednocześnie do Wojewódzkiego Sądu Administracyjnego w Warszawie została wniesiona skarga na decyzję Szefa Urzędu do spraw Cudzoziemców wraz z wnioskiem o wstrzymanie wykonania decyzji do czasu rozpoznania sprawy przez są, ponieważ jej wykonanie spowoduje dla cudzoziemca znaczną szkodę i trudne do odwrócenia skutki. Skarżący wskazał, że przebywa w Polsce legalnie, przestrzega porządku prawnego, chciałby założyć tu rodzinę, obecnie jest w trakcie przygotowywania doktoratu, tak więc wyjazd z Polski spowoduje skreślenie go z listy studentów studiów doktoranckich, a także uniemożliwi mu uczestnictwo w rozprawie przed sądem. Jednakże w 21 lipca 2010 r. Wojewódzki Sąd Administracyjny w Warszawie oddalił jego skargę.

W świetle powyższych regulacji u.o.c. uzasadnione wątpliwości budzi ponadto ratio legis art. 329a:

1. Minister właściwy do spraw wewnętrznych, na wniosek Komendanta Głównego Policji, Szefa Agencji Bezpieczeństwa Wewnętrznego albo Szefa Służby Kontrwywiadu Wojskowego, wydaje decyzję o zobowiązaniu cudzoziemca do powrotu dotyczącą cudzoziemca, co do którego istnieje obawa, że może prowadzić działalność terrorystyczną lub szpiegowską, albo podejrzewanego o popełnienie jednego z tych przestępstw. 2. Decyzja, o której mowa w ust. 1, podlega natychmiastowemu przymusowemu wykonaniu.

Przepis ten obowiąuje od 2 lipca 2016 r.

Wymaga podkreślenia, że ustawodawca nie wyjaśnił zakresu zastosowania wskazanego przepisu ani jego celu. Prezentowana regulacja jest nieprzejrzysta i zbyt ogólnikowa, co może w praktyce prowadzić do daleko idącej dowolności i arbitralności w jej stosowaniu przez organy administracyjne. Należy bowiem zauważyć, iż zawarte w cytowanym przepisie zwroty „działalność terrorystyczna lub szpiegowska” mieszczą się co prawda w zakreślonych w doktrynie i orzecznictwie przesłankach związanych z ochroną bezpieczeństwa i porządku publicznego, niemniej jednak prawodawca nie wskazał żadnych kryteriów służących ocenie, co należy rozumieć przez pojęcie „istnieje obawa”, ani nie zdefiniował, co oznacza „działalność terrorystyczna”. Tym samym art. 329a nie wnosi zasadniczo nowych treści w porównaniu z już wcześniej obowiąująca regulacją na gruncie art. 302 ust. 1 pkt 9 w związku z art. 315 ust. 5 u.o.c. 
W świetle standardu EKPC konstrukcja prawa cudzoziemca do ochrony przed arbitralnym wydaleniem z państwa legalnego pobytu zakłada zarówno ochronę interesów państwa, jak i cudzoziemca. Organy RP mogą podjąc decyzję o wydaleniu cudzoziemca wyłącznie, gdy stanowi on realne i wystarczająco poważne zagrożenie dla porządku publicznego lub bezpieczeństwa państwa, opierając się na ocenie konkretnych okoliczności faktycznych. Gdy cudzoziemiec wejdzie w konflikt $\mathrm{z}$ prawem, należy na wstępie ocenić charakter i wage przestępstwa przez niego popełnionego.

Nie ulega wątpliwości, że bezpieczeństwo publiczne, jako wartość usprawiedliwiająca ograniczenie przez ustawodawcę korzystania z praw i wolności człowieka, wymaga zachowania proporcjonalności dopuszczalnej ingerencji w imię ochrony bezpieczeństwa oraz sprawnego systemu kontroli zachowania tej proporcjonalności w praktyce. W przeciwnym razie środki ochrony tego bezpieczeństwa same $\mathrm{w}$ sobie stwarzają zagrożenie dla tych praw i wolności, jeżeli wprowadzane ograniczenia będą arbitralne, nieproporcjonalne do ewentualnych zagrożeń ze strony cudzoziemców oraz gdy będą one wyłączone spod kontroli sprawowanej przez instytucje demokratyczne.

Należy uznać, że uchwalony niedawno przez ustawodawcę art. 329a u.o.c. nie spełnia wymogu przewidywalności i precyzyjności prawa. Zgodnie z kryterium jakości prawa przyjętym przez ETPC, skutki normy prawnej sa przewidywalne, jeżeli norma ta jest sformułowana z wystarczająca precyzja, w sposób umożliwiający każdej jednostce - w razie potrzeby po uzyskaniu stosownej porady - przyjęcie określonego sposobu postępowania. Dodatkowo prawo krajowe musi zapewniać środek ochrony prawnej przed arbitralna ingerencją władzy publicznej w prawa zagwarantowane przez Konwencję ${ }^{45}$. Jednakże treść analizowanego przepisu u.o.c. nie zapewnia cudzoziemcowi ochrony przed arbitralną ingerencją ze strony tych podmiotów.

\section{WNIOSKI}

Państwo, wykonując swoją funkcję wewnętrzną, stanowi prawo, ale także zaciaga zobowiązania międzynarodowe, w związku z czym prawo polskie nie powinno pozostawać w sprzeczności z tymi zobowiązaniami. Przy podejmowaniu decyzji o wydaleniu cudzoziemca z terytorium Rzeczypospolitej Polskiej należy wziać pod uwagę, że nawet w sytuacjach, gdy przepisy krajowe nakazuja jego wydalenie, ochrona może wynikać expressis verbis z postanowień innych aktów prawnych, tj. umów międzynarodowych ratyfikowanych przez Polskę, obejmujacych ochronę praw jednostki.

Wymaga podkreślenia, że im bardziej precyzyjnie i klarownie są sformułowane podstawy wydalania cudzoziemców, tym lepiej państwo realizuje obowiazek poszanowania praw przysługujacych cudzoziemcom na podstawie art. 1 Protokołu nr 7 do EKPC. W świetle orzecznictwa ETPC polskie organy powinny dokonywać oceny tego, czy względy ochrony porządku publicznego

${ }^{45}$ Orzeczenie ETPC z 20 czerwca 2002 r., Al-Nashif p. Butgarii, skarga nr 50963/99, par. 119. 
lub bezpieczeństwa państwa wymagaja natychmiastowego wydalenia cudzoziemca, w sposób indywidualny, pozwalajacy ustalić, czy osobiste zachowanie danego cudzoziemca stanowi rzeczywiste, aktualne i dostatecznie poważne zagrożenie dla jednego z podstawowych interesów społeczeństwa. Przy dokonywaniu tej oceny organy powinny uwzględnić każdą okoliczność faktyczną lub prawną związaną z sytuacją danego cudzoziemca, która może pomóc rozstrzygnać kwestię, czy jego osobiste zachowanie stanowi takie zagrożenie. Tym samym wykluczony jest automatyzm w wydalaniu cudzoziemców.

Nie ulega wątpliwości, że problematyka poinformowania cudzoziemca o względach bezpieczeństwa państwa uzasadniających jego wydalenie jest złożona i może w pewnych sytuacjach pozostawać w konflikcie z koniecznościa prawidłowego działania wymiaru sprawiedliwości. Należy jednak podkreślić, że realizacja prawa do obrony jest możliwa tylko wtedy, gdy powody wydalenia są komunikowane cudzoziemcowi w sposób na tyle konkretny, że pozwalają mu przedstawić swoje stanowisko i podjać próbę zakwestionowania ustaleń dokonanych przez właściwe organy. Istnienie odpowiednich mechanizmów procesowych, które mogą zagwarantować zadowalajacy poziom rzetelności, jest nieodzowne dla skutecznej ochrony przed arbitralnym wydaleniem. W tym celu ustawodawca powinien zapewnić jednocześnie zachowanie poufności danych związanych z bezpieczeństwem państwa i korzystanie z prawa do obrony przez osobę wydalaną. W każdym przypadku należy zbadać, czy została zapewniona odpowiednia równowaga między ochroną interesów cudzoziemca a wymogami związanymi z bezpieczeństwem państwa.

dr Julia Wojnowska-Radzińska

Uniwersytet im. Adama Mickiewicza w Poznaniu

juliaw@amu.edu.pl

\author{
THE PROHIBITION AGAINST ARBITRARY EXPULSION \\ OF ALIENS UNDER ARTICLE 1 OF THE PROTOCOL NO. 7 \\ TO THE ECHR AND ITS IMPLEMENTATION IN POLISH LAW AND PRACTICE \\ - SELECTED ISSUES
}

Sum mary

This article provides an overview of the prohibition against arbitrary expulsion of aliens under Article 1 of the Protocol No. 7 to the ECHR and its implementation in Polish law and practice. The provision discussed in the article provides an alien with procedural guarantees against arbitrary expulsion. It should be noted that the analysed regulation stipulates that an alien who is lawfully in the territory of a State may be expelled only in pursuance of a decision reached by a competent authority in accordance with domestic law. The independent courts must be able to react in cases where a Polish authority invokes a threat that an alien poses to national security with no reasonable basis in fact or reveals an arbitrary interpretation of national security. The argument that a lawful alien poses a serious threat to national security or public order as a reason to expel him/her cannot be based on vague; unproven and anonymous allegations or unspecified information contained in a secret internal document. 
